\title{
Nação, nacionalismo, Estado
}

\author{
SAMUEL PINHEIRO GUIMARÃES
}

\section{Definições}

$\mathrm{N}$ AÇÃo, em seu sentido político moderno, é uma comunidade de indivíduos vinculados social e economicamente, que compartilham certo território, que reconhecem a existência de um passado comum, ainda que divirjam sobre aspectos desse passado; que têm uma visão de futuro em comum; e que acreditam que esse futuro será melhor se se mantiverem unidos do que se separarem, ainda que alguns aspirem modificar a organização social da nação e seu sistema político, o Estado.

Nesse sentido, é possível falar de uma nação brasileira, de uma nação mexicana, de uma nação indiana, de uma nação americana, e assim por diante, ainda que grupos sociais dentro dessas nações possam ter interpretações diferentes de seu passado e aspirações distintas para seu futuro em comum, sem, todavia, que nenhum grupo significativo chegue a desejar e a lutar pela secessão.

Nacionalismo é o sentimento de considerar a nação a que se pertence, por uma razão ou por outra, melhor do que as demais nações e, portanto, com mais direitos, sendo manifestações extremadas desse sentimento a xenofobia, o racismo e a arrogância imperial. Nacionalismo é, também, o desejo de afirmação e de independência política diante de um Estado estrangeiro opressor ou, quando o Estado já se tornou independente, o desejo de assegurar em seu território um tratamento pelo Estado melhor, ou pelo menos igual, ao tratamento concedido ao estrangeiro, seja ele pessoa física seja jurídica. Os movimentos nacionalistas significativos do ponto de vista político, cujas manifestações históricas mais simples decorrem de identidade étnica, lingüística ou de pertencimento, no passado, a uma organização política, têm como seu principal objetivo o estabelecimento de um Estado ou a modificação das políticas do Estado para defender ou privilegiar interesses dos que integram certo movimento.

\section{Nacionalismo}

O preconceito de considerar a sua nação melhor do que as demais tem sua origem na idéia de que as divindades teriam escolhido um povo, uma certa nação, como eleita, isto é, a nação como um conjunto de indivíduos que adoravam uma certa divindade. O caso do povo judeu, o chamado povo eleito, é clássico, e essa convicção tem conseqüências políticas até hoje, sendo talvez o Oriente Próximo o principal e mais complexo foco de tensão no mundo. O Japão é outro caso interessante na medida em que o imperador era considerado Filho do Sol e como tal simbolizava o vínculo concreto entre o povo japonês e a divindade suprema. A China, tradicionalmente, se considerava tão superior aos povos 
vizinhos e mesmo a povos distantes que nem sequer admitia manter relações políticas em nível de Estados soberanos com outros Estados. Esses podiam, no máximo, oferecer tributos ao Império do Meio, centro da civilização, cujos imperadores se acreditava estarem diretamente vinculados às divindades celestiais.

O caso dos Estados Unidos, civilização mais recente do que a chinesa, a judaica e a japonesa (e mesmo a francesa, a alemã e a russa), é distinto, mas as raízes do nacionalismo americano podem ser encontradas na religião protestante. Essa considera que o sucesso material é um sinal de aprovação divina, da própria salvação, de uma predestinação. De um ponto de vista coletivo, o sucesso material da sociedade americana significaria um sinal de aprovação divina, de que a sociedade americana seria eleita pelo Senhor e que, por essa razão, não só poderia como deveria assumir o papel de líder e de modelo para todas as sociedades e Estados. Essa missão salvadora dos Estados Unidos se encontra claramente expressa nos documentos de política externa dos Estados Unidos. A declaração do presidente George W. Bush de que teria, literalmente, falado com Deus, a presença crescente e a enorme influência do fundamentalismo religioso, extremamente conservador, belicoso e nacionalista são aspectos, fatos reveladores dessa convicção de povo, de nação eleita e, portanto, de superioridade em relação às demais nações.

Um dos principais movimentos nacionalistas viria a se desenvolver na Alemanha com base na superioridade de uma suposta raça ariana, germânica e pura que viria a redundar na tomada do Estado pelo Partido Nacional Socialista, com terríveis conseqüências para o mundo e, em especial, para aqueles que considerava como integrantes das raças inferiores, em especial os judeus, vítimas de uma política de eliminação física, o Holocausto.

O nacionalismo nos países desenvolvidos, em especial nas Grandes Potências, e sua pretensão de superioridade nacional redundaram facilmente em políticas expansionistas e agressivas, tanto no continente europeu como também na formação dos impérios coloniais, com a noção explícita de inferioridade dos povos e das culturas locais e até, eventualmente, a idéia de que seriam seres humanos distintos e mesmo inferiores. Em um exemplo chocante dessa pretensão, o general Westmoreland, então comandante-em-chefe das forças americanas no Vietnã, se referiu publicamente aos vietnamitas como seres diferentes "de nós", para justificar certas ações das tropas americanas.

Assim, a característica central do sistema internacional nos últimos quinhentos anos desde a descoberta das Américas tem sido o imperialismo e o colonialismo, cujo fundamento de dominação, além da força, foi a ideologia de superioridade racial e civilizacional em relação às colônias e a seus povos e a agressão aos sistemas políticos, sociais e culturais de nações dominadas, pela força, pelas metrópoles européias (o que também ocorreu no processo de criação dos "impérios continentais" como na expansão territorial dos Estados Unidos rumo ao Oeste, e da Rússia rumo ao Leste e ao Sul). A escravidão foi a expressão máxima dessa dominação e os escravos eram considerados seres inferiores, sem 
alma, e portanto naturalmente sujeitos ao jugo e ao arbítrio de seus senhores. Lord Acton, em artigo publicado em 1862, afirmava que os Estados mais perfeitos são aqueles que, como o Império Britânico e o Império Austríaco, incluíam várias nacionalidades distintas sem as oprimir porque "as raças inferiores se elevam ao viver em união política com raças intelectualmente superiores".

Nos países da periferia, ex-colônias, ou ex-semicolônias, o nacionalismo tem natureza radicalmente distinta dos movimentos nacionalistas que se desenvolveram na Europa, os quais tiveram sua reputação definitivamente manchada pelo nazi-fascismo, que tinha, aliás, seguidores e simpatizantes ardorosos em vários outros países europeus, além de Alemanha e Itália. Diga-se de passagem que os atuais "cosmopolitas" utilizam muitas vezes uma identificação errônea entre o nacionalismo europeu e o nacionalismo da periferia para desqualificar os movimentos anticolonialistas, antiimperialistas e hoje antiglobalização acusando-os de "nacionalistas" (ao que em geral acrescentam o termo populista). Os movimentos nacionalistas nas diversas colônias, com a variação natural de tempo e espaço, foram movimentos de afirmação da nacionalidade, de recuperação de tradições, de idioma, de autonomia política e de independência, em relação inicialmente às metrópoles coloniais européias, e, mais tarde, se transformaram em movimentos de afirmação política e de desenvolvimento econômico independente dos Estados que se originaram nas ex-colônias.

\section{Nação}

Ao final do Império Romano, as invasões das tribos bárbaras que viriam a ocupar as províncias romanas e a estabelecer os feudos, territórios em que os diversos líderes tribais tinham reconhecida sua soberania política e militar, ainda que mais ou menos limitada, estabelecem pela primeira vez, pela diferenciação de idiomas e de raças em fusão com os habitantes, as línguas locais e o latim popular, as sementes das nações e dos Estados modernos. A Igreja nesse processo teve especial relevância na medida em que esses senhores feudais iriam se convertendo ao cristianismo e reconheciam a autoridade de Roma.

Esses sistemas feudais, frouxamente submetidos a um poder central, em geral o senhor de um feudo territorial e populacionalmente maior, correspondiam a um conjunto de feudos, territórios pequenos que, por força dos diversos sistemas de herança política (que aliás era também patrimonial), do regime de morgadio e de casamentos, viriam a se agregar progressivamente. As divergências sobre direitos hereditários, as guerras de conquista e a relação pessoal patrimonial dos senhores feudais com os seus territórios fariam que periódica e eventualmente populações de distintas origens passassem a estar submetidas à soberania de distintos senhores.

Assim se formaram os Estados Nacionais europeus, os quais, na realidade, não correspondiam a nações homogêneas, mas agrupavam populações de distintas origens étnicas, com diferentes graus de miscigenação, com distintas tradições e, às vezes, religiões. Nesses Estados vigiam regimes absolutistas cujo 
fundamento era a doutrina do direito divino dos reis sobre todos os seus súditos (incluindo os nobres descendentes dos senhores feudais), monarcas que se apoiavam mutuamente nessa pretensão. Esses monarcas absolutos tinham o suporte ideológico de Roma, até que o protestantismo veio a opor ferozmente, em guerras sangrentas, alguns desses Estados, que continuavam, todavia, a acreditar e a defender a doutrina do direito divino dos reis.

A idéia de que o Estado nasce com a nação não corresponde à realidade na maior parte dos casos, pois a nação seria de fato uma construção ideológica posterior, tendo muitas vezes a nação sido "construída" pelo Estado. A emergência natural das nações teria sido em realidade impossível em razão da ignorância das massas, da diversidade de etnias e de religiões, da ausência de tradições reais, efetivas, da tardia fixação das línguas, das difusas tradições orais e, portanto, a emergência de uma nação teria sido somente possível após o surgimento do Estado moderno, que organiza uma administração central do Estado, e como conseqüência dos programas de educação pública, do serviço militar e da vontade dos dirigentes de unificar as populações. Todavia, se isso ocorre, ou seja, se as nações foram construídas pelos Estados, torna-se necessário procurar esclarecer como surgiram os Estados.

Assim, nação e nacionalismo, apesar de serem conceitos difusos, correspondem a realidades que tiveram e têm forte impacto sobre a realidade política e se encontram estreitamente vinculadas a um outro conceito que, além de conceito, é o fato mais concreto da realidade cotidiana de todos os indivíduos, que é o Estado. Todas as questões teóricas e práticas relativas a nação e a nacionalismo, como em que medida a cada nação deveria corresponder um Estado; se as nações para serem consideradas como tal deveriam ser étnica, idiomática ou religiosamente homogêneas; se o nacionalismo seria sempre uma manifestação política perversa e perigosa; se o nacionalismo tende ao nazismo, e assim por diante, passam a ter um interesse especial quando examinadas à luz da noção e da realidade do Estado.

\section{A formação primitiva dos Estados}

Apesar das diferenças importantes no processo de formação e de evolução dos atuais Estados, uma descrição geral um tanto ou quanto esquemática de sua formação pode ser feita, a qual teria de se ajustar e de ser qualificada, com as mudanças necessárias, a cada circunstância histórica e geográfica de Estados específicos, mas cuja dinâmica geral poderia ser considerada razoavelmente válida para todos.

A diversificação das atividades produtivas e das funções sociais acarretava, mesmo nas sociedades mais primitivas, conflitos de interesses que tornavam necessária a existência de normas que disciplinassem as relações entre indivíduos e grupos, e que, sendo aceitas, ou impostas, como válidas por todos, permitiam sua convivência social pacífica sem que fosse necessário recorrer permanentemente à força e à violência para garantir sua obediência. 
A luta pela hegemonia (isto é, pelo direito de extrair riquezas naturais em um certo território e de nele organizar o trabalho humano) levava à sujeição de umas comunidades por outras e à definição de territórios e de suas fronteiras, dentro das quais essa hegemonia se exercia na prática pela definição de normas e pela capacidade de fazê-las aceitar se necessário pela força.

Naturalmente, os grupos hegemônicos em cada sociedade procuravam justificar e explicar sua hegemonia por meio de seus supostos vínculos com as divindades protetoras daquelas comunidades as quais lhes conferiam o direito de governá-las e, portanto, de elaborar as normas de conduta e de zelar pelo seu cumprimento.

As fronteiras separavam territórios geográficos dominados por distintos grupos hegemônicos cujos líderes procuravam acentuar as diferenças que existiam em relação a cultura, idioma, tradições e práticas religiosas entre as comunidades separadas por fronteiras e assim incentivavam a rivalidade e as noções de superioridade, que caracterizam os nacionalismos.

As fronteiras definem os limites físicos do exercício de hegemonia (de soberania) dos grupos e se estabeleceram no passado como resultado de processos de luta que vieram a se fixar em obstáculos naturais ao exercício eficaz da força, tais como mares, lagos, rios e cadeias de montanhas, obstáculos que contribuíram no passado, quando as distâncias eram muito significativas, para o desenvolvimento de tradições e idiomas distintos.

À medida que as sociedades se tornavam mais populosas, surgia a necessidade de organizar instituições permanentes, encarregadas de elaborar as normas de conduta, de assegurar a obediência a elas e de financiar o seu funcionamento, mediante coleta de tributos. Nas comunidades primitivas e menores, todos os indivíduos podiam participar da elaboração de normas sociais e todos podiam, em princípio, participar dos organismos sociais encarregados de zelar pela obediência a essas normas.

À medida que as comunidades cresciam em população e que se diversificavam as atividades produtivas, os indivíduos deixavam de poder participar diretamente dos processos de elaboração e de execução de normas e de solução de conflitos. Tornava-se necessário escolher representantes, para governar as sociedades por meio de sistemas cujas diferenças decorriam, como Aristóteles definiu na Politica, de um julgamento apriorístico sobre a natureza humana. A questão básica, segundo Aristóteles, seria a de saber se todos os indivíduos seriam essencialmente iguais ou desiguais; e, caso desiguais, se uma família poderia ser considerada melhor do que as demais; ou se alguns indivíduos seriam considerados essencialmente melhores do que os demais. Dependendo da natureza dessa convicção apriorística, os regimes políticos possíveis seriam a democracia, a monarquia e a oligarquia, com suas variações. É óbvio, todavia, que nunca houve um debate teórico sobre a natureza humana prévio à definição dos regimes políticos das comunidades humanas, primitivas ou não, os quais se definiram, 
isso sim, a partir do intenso conflito de interesses dentro de cada comunidade e da luta dos diversos grupos pela hegemonia.

De toda forma, mesmo na monarquia absoluta e nos regimes autoritários, o rei ou o ditador não governa sozinho, não elabora as normas de conduta sozinho nem sozinho garante a obediência a elas. Tem ele de se fazer valer de auxiliares, nobres, ministros, apparatchiks ou que nome tenham, aos quais delega o exercício de parte de suas funções e prerrogativas e de cujo apoio político e militar necessita para se manter no poder. É possível imaginar que, no início, a escolha desses indivíduos se fazia especialmente no seio daquelas famílias dos grupos hegemônicos que organizaram inicialmente a comunidade e seus sistemas de produção e de defesa contra outras comunidades.

Os distintos regimes políticos, formas de governo, são apenas distintos sistemas de seleção dos representantes de uma comunidade para exercer as funções públicas e da forma de financiar o exercício dessas funções, que são legislar, executar e julgar. O conjunto de instituições que exercem essas funções de legislar, executar e julgar em nome do conjunto dos cidadãos de uma sociedade se chama Estado. Uma função essencial e preliminar do Estado é a organização de sua defesa em relação às pretensões territoriais de outros Estados e assim garantir a sua soberania sobre o seu território e a população que nele habita. O Estado, ainda que em suas formas primitivas e de alcance pouco abrangente, é, portanto, essencial para a convivência pacífica dos diversos grupos de indivíduos que habitam um determinado território e para a defesa de seus interesses em confronto com outras comunidades organizadas sob a forma de Estado. Naturalmente que os sistemas religiosos, com suas normas de conduta social e com o poderoso instrumento de sua sanção divina, faziam parte integrante dos Estados.

O Estado moderno detém o monopólio do uso da força que é sua prerrogativa essencial e indispensável para a manutenção eficiente de um sistema de normas e de governo.

A evolução histórica das comunidades primitivas por meio de guerras, da conseqüente incorporação de territórios e de sujeição da população neles existentes levou eventualmente à constituição dos Estados modernos. Naquelas circunstâncias em que essa incorporação de território e de população não foi aceita se verificam hoje as reivindicações mais ou menos violentas por autonomia ou independência, tais como ocorrem na Espanha, na China, na Iugoslávia, na exURSS, no Canadá, na Bélgica e em tantos outros países.

Essa evolução histórica das comunidades e nações levou à constituição e à definição dos territórios dentro dos quais se exerce a soberania de cada um dos 192 Estados atuais membros da Organização das Nações Unidas (ONU), cuja convivência pacífica somente se pode dar com obediência aos princípios dos Artigos 1 e 2 da Carta: solução pacífica de controvérsias; direitos iguais e autodeterminação; respeito pelos direitos humanos e liberdades fundamentais; igualdade soberana; abstenção de ameaças ou de uso da força contra a integridade territorial e a independência política de qualquer Estado. 
A Revolução Francesa em 1789, a Revolução Russa em 1917 e a Revolução Chinesa em 1949 foram três grandes tentativas de modificação do sistema social e da organização do Estado, com enormes reflexos na história da humanidade: a primeira desencadeou o processo de eliminação dos direitos feudais e de transformação das monarquias absolutas na Europa (e de seus impérios coloniais, em especial na América Latina) ao afirmar que "cada povo é independente e soberano"; a segunda iniciou a primeira experiência de um modelo social e político alternativo ao capitalismo e ao liberalismo e reforçou, em competição com os Estados Unidos, que a advogava somente para os europeus, a idéia de autodeterminação dos povos; e a terceira iniciou o processo de transformação do Estado e da economia chinesa com as conseqüências que hoje fazem que a China, ao crescer em média $10 \%$ ao ano nos últimos vinte anos, se tenha transformado na segunda maior potência econômica do mundo.

\section{A visão do Estado no início do século XXI}

A sociedade atual se caracteriza pela concentração de riqueza e de poder, pela transformação tecnológica acelerada, pela instabilidade social, pela ansiedade e frustração individual, pelo fundamentalismo religioso e pelo consumo de produtos que alteram a consciência, tais como o álcool, a cocaína, o ecstasy e outros narcóticos.

Nessa sociedade moderna, quer seja ela altamente desenvolvida quer seja subdesenvolvida, o controle do Estado, isto é, o controle do sistema de normas e de instituições que definem e garantem as características fundamentais do sistema de produção e que, não importa a razão, consagram certos privilégios, é essencial para as classes dominantes.

No sistema democrático moderno, todavia, que é o resultado de uma história de lutas e de conquistas dos setores oprimidos da sociedade, a cada cidadão, conceito esse que vem sendo definido de formas diferentes ao longo do tempo e do espaço, cabe um voto no processo de escolha dos dirigentes do Estado. Por sua vez, no capitalismo, a cada unidade monetária corresponde um "voto" no mercado e, portanto, as decisões sociais sobre o que produzir, como produzir, como consumir, e os benefícios que decorrem dessas decisões se encontram altamente concentradas nas mãos das megaempresas, isto é, de seus acionistas-proprietários e de seus delegados, ou mais bem empregados, os chamados executivos.

O grande e permanente desafio que têm de enfrentar os detentores do poder econômico na sociedade moderna de regime democrático, em que a cada cidadão corresponde um voto, consiste em como transformar poder econômico em poder político. Essa transformação é essencial para garantir a sobrevivência das normas fundamentais do sistema econômico e social e, eventualmente, para promover, à medida que isso se torna necessário, sua modificação controlada, reformista e não-revolucionária, isto é, sem alterar as relações fundamentais de propriedade. Nos primórdios da democracia liberal, tal desafio ainda não se co- 
locava, pois o regime era censitário, os indivíduos somente eram cidadãos na medida em que tinham certa renda, ou propriedade, ou pagavam impostos.

A primeira meta, portanto, no processo de transformar poder econômico em poder político deve ser afastar a massa de cidadãos das atividades do Estado e da política, que é a atividade pela qual se controla o Estado, ou reduzir ao mínimo e controlar a participação dessa massa na política e no Estado. Assim, é necessário difundir uma imagem negativa do Estado e da política no seio da massa da sociedade, mas certamente não entre os que compõem as suas elites.

A imagem do Estado que se difunde na sociedade atual, em que predominam os valores individualistas, exaltados pela mídia, pelo sistema educacional e até pelas religiões, é que o Estado é o moderno Leviathan, a fonte de todo o Mal.

De acordo com essa visão, a cobrança de impostos extorsivos (por menores que sejam em realidade) para alimentar uma burocracia parasitária, que se compraz em elaborar milhares de regulamentos inúteis e confusos, que estimulam a corrupção e tolhem a liberdade e a criatividade do indivíduo, puro e feliz originalmente, decorre da existência de um Estado que todos os dias infringe a liberdade individual e entorpece o desenvolvimento da sociedade. Essa visão, que persiste ao longo dos séculos, se origina na crítica às práticas arbitrárias das monarquias absolutas do renascentismo e do iluminismo contra as quais a burguesia nascente e seus representantes políticos lutaram para poder implantar o capitalismo e o liberalismo como formas de organização econômica e política, em uma época anterior à revolução industrial e à revolução tecnológica.

Nesse Estado Leviathan do século XXI, reinaria maleficamente o político, o homem do Estado, o homem do Mal. Incompetente, é incapaz de enfrentar os males que afligem a sociedade; mentiroso, ilude os cidadãos a quem periodicamente atraiçoa; xenófobo, estimula os conflitos; e corrupto, defende os interesses estrangeiros, ou os interesses dos poderosos ou os interesses dos incompetentes sociais que fracassaram na luta individualista pelo sucesso, enquanto se aproveitam das "vantagens" dos cargos que ocupam.

O desprezo e até o horror pela política (e pelos políticos) são sistemática e cotidianamente estimulados pelos meios de comunicação de massa, que procuram fazer crer aos integrantes das classes médias e trabalhadoras que a atividade política não é digna de um "homem de bem", que esse deve dedicar-se exclusivamente à sua atividade profissional seja ele um operário, um empregado, um técnico, seja um profissional liberal, sob o risco de se corromper.

Na estratégia de estimular esse horror e desprezo (com o objetivo de afastar as "classes inferiores" da tentação de governar a sociedade), é necessário desmobilizar essas "classes", desviar e distrair sua atenção, o que é tanto mais importante quanto mais desigual e excludente for a sociedade, e, portanto, quanto maior for a ostentação de riqueza e mais gritante a miséria.

A distração da atenção das grandes massas trabalhadoras e das classes médias se faz pela criação de novos cultos e da promoção dos heróis desses novos 
cultos. A promoção desses novos cultos e a promoção desses novos heróis são feitas pelos meios de comunicação de massa, em especial a televisão, e pela oferta maciça de entretenimento banal audiovisual, dos espetáculos musicais, dos folhetins, dos espetáculos esportivos, dos anúncios publicitários. A sociedade é a do espetáculo, em que tudo se transforma em espetáculo, incluindo a política.

O principal desses novos cultos é o culto do corpo, que se realiza por meio do "body building", da engenharia plástica e das dietas corretas de alimentação (a dieta da sopa, das frutas, das proteínas, do tipo sangüíneo, das vitaminas...) e seus heróis são os atletas, os artistas e as modelos de moda, enquanto se depreciam o espírito e a cultura, mais pela omissão do que pelo ataque direto.

O segundo culto é o do dinheiro, em que o empresário se apresenta como o grande herói, dinâmico, astuto, trabalhador incansável em busca do sucesso pessoal, e se procura convencer a todos que todos podem vir a se tornar empresários bem-sucedidos e ricos, bastando seguir as estratégias descritas nos títulos da literatura de auto-ajuda empresarial: E se Harry Potter dirigisse a General Eletric?, Casais inteligentes ficam ricos, o Tao de Warren Buffet, Sun Tzu - a Arte da guerra para os executivos etc. O empresário é, assim, o herói que enfrenta o político vilão, é vítima e adversário do Estado, dá emprego às massas, é a favor da paz. Os heróis desses dois novos cultos são os modelos para os jovens e o escárnio dos idosos que já não podem ser atletas nem empresários, fracassados por não serem ricos e cuja experiência não tem valor na sociedade do novo e da obsolescência programada.

O mundo ideal, para os indivíduos da nova sociedade do século XXI, de onde são enxotadas as utopias, ridicularizadas sempre que propõem enfrentar as desigualdades sociais e modificar as estruturas de poder que as originam e mantêm, seria um mundo sem governos, sem violência, sem drogas, sem políticos, sem normas, sem impostos, onde todos seriam física e financeiramente bem-sucedidos, atletas e empresários, um mundo em que, acima de tudo, o Estado não existiria.

\section{O mundo real do século XXI}

No mundo real do século XXI, existem 192 Estados e um número ainda maior de nações, e, portanto, trata-se de um mundo em que proliferam os conflitos e as divergências dentro e entre os Estados, e em que a elaboração permanente de normas e a atividade política incessante são realidades inescapáveis.

Não só existem hoje 192 Estados, mas o número de Estados vem crescendo desde que, em 1946, a Carta das Nações Unidas foi subscrita por seus Estados fundadores. Os Estados membros da ONU de 51, em 1946, passaram a 152, em 1980, e a 192, em 2008, e à medida que os nacionalismos se aguçam, estimulados ou naturais, outros Estados podem vir a surgir, como foi o caso recente do Kosovo, Estado de grande inviabilidade, mas que abre importante precedente, que afeta os interesses mais estratégicos dos Estados Unidos e da Europa. O estímulo aos nacionalismos locais na Europa enfraquece o novo nacionalismo europeu que se concretizaria na "cidadania européia", ao tornar mais 
difícil a ação política da União Européia, enquanto o estímulo aos nacionalismos na periferia tem o efeito de enfraquecer os grandes Estados como a China, a Índia e a Rússia. Politicamente, se fortalecem os nacionalismos, o que enfraquece esses grandes competidores; economicamente, isso prejudica o processo de globalização ao multiplicar o número de Estados.

Os conflitos armados durante o século XX foram os mais sangrentos e destrutivos de toda a história da humanidade, e o fim dos regimes comunistas, a cuja existência e ação se atribuía os conflitos entre Estados, não reduziu nem o número nem a intensidade desses conflitos.

O aumento do número de Estados decorreu certamente da vitalidade e do sucesso dos movimentos nacionalistas em sua luta contra a dominação dos impérios coloniais e contra os Estados sob cuja dominação se encontravam grupos nacionais irredentos, tais como ocorria na Checoslováquia, na Iugoslávia e na União Soviética.

A formação dos Estados foi certamente distinta na Europa, na América Latina, na África e na Ásia. Os Estados atuais, em especial na América Latina, onde as instituições das populações locais existentes à época da conquista ou foram totalmente eliminadas, como no caso do México e do Peru, ou eram frágeis, como no caso do Brasil, são o resultado muitas vezes da evolução do transplante de instituições européias feito pelas metrópoles para suas colônias. Na África, século e meio mais tarde, as colônias tiveram fronteiras arbitrariamente traçadas que, mais tarde, sobreviveram ao processo de descolonização, separando etnias, idiomas e tradições, e dando uma razão para os conflitos que, todavia, muitas vezes, têm sua verdadeira origem em disputas pela exploração de recursos naturais. Na Ásia, a colonização européia se fez de forma mais indireta e encontrou sistemas políticos e administrativos muito mais sofisticados aos quais se superpôs. Hoje aquelas formas anteriores de organização, ou pelo menos seu espírito, sobreviveram nas organizações políticas do Estado asiático.

Por sua vez, o atual processo de integração européia não é um processo de eliminação do Estado e de suas características fundamentais, mas sim um processo de unificação gradual de Estados independentes que cedem parte da sua soberania aos órgãos supranacionais da União Européia. Esse é um fenômeno semelhante ao que ocorreu no passado na Alemanha e na Itália, e nada tem a ver com alguma suposta tendência histórica ao fim das fronteiras, mas sim corresponde a um redesenhar de fronteiras e de cidadania. Trata-se em realidade da formação gradual de um novo (e enorme) Estado em um processo semelhante, mas de nenhuma forma igual (pois os Estados, na União Européia, ainda conservam um número muito maior de prerrogativas soberanas) ao que sucedeu na formação dos Estados Unidos, da Alemanha e da Itália.

\section{O capitalismo e a campanha pelo fim do Estado}

O capitalismo moderno tem como fundamento a propriedade privada dos meios de produção e, como objetivo principal, o lucro. Esse objetivo supremo 
torna indispensável a permanente expansão da produção a qual depende, por sua vez, da divisão do trabalho e, portanto, da extensão do mercado.

Quanto maior a extensão do mercado, maior a possibilidade de divisão do trabalho, maior a produtividade, maior a produção, maior o consumo, maior o lucro e maior a felicidade humana, já que, conforme Jeremy Bentham argumentou, seria impossível medir o grau de felicidade humana e assim se poderia considerar que quanto mais bens o indivíduo (e a comunidade) puder consumir maior a sua "felicidade". Daí a alegria com que se saúdam os incrementos do PIB, enquanto se constata o alto grau de insatisfação do indivíduo comum mesmo naqueles países mais desenvolvidos. Claro está que, para as massas de excluídos, o aumento de sua "felicidade" somente poderá ocorrer quando conseguirem alcançar patamares mínimos e dignos de consumo de bens físicos e culturais.

Assim, o capitalismo, como forma de organização da produção, da distribuição e do consumo de bens, desde os seus primórdios, procurou ampliar os mercados mediante a incorporação de forma pacífica ou violenta de populações e de territórios ao seu sistema de produção, e assegurar a existência de sistemas políticos de elaboração e de execução de normas que garantissem sua expansão e seu funcionamento pacífico.

Esse processo de formação de mercados, de início locais, em seguida regionais, depois nacionais, posteriormente continentais e, finalmente, globais foi interrompido no período que decorreu entre 1914 e 1989, em que se verificaram as duas Guerras Mundiais, a Grande Depressão de 1929 e a Revolução Bolchevique de 1917, que implantou o regime socialista na Rússia e que viria a se expandir para a Europa Oriental, a China e a Ásia. O processo de descolonização, por sua vez, iria em muitos Estados de independência recente levar à organização de sistemas de produção de economia mista com alto grau de participação do Estado, o mesmo tendo ocorrido na América Latina. Esses eventos fragmentaram de diversas formas a economia mundial, interrompendo o processo de globalização de mercados e de integração da economia mundial, e chegaram a parecer a muitos analistas como o prenúncio de uma eventual, mas certa, derrota do capitalismo diante do comunismo.

A queda do Muro de Berlim, a retirada das tropas soviéticas da Europa Oriental e do Afeganistão, a desintegração da União Soviética em quinze Estados independentes, a adesão ao capitalismo dos antigos regimes comunistas europeus, a nova política econômica na China, a reorganização das economias das ex-colônias da periferia por meio das condicionalidades vinculadas ao processo de renegociação de suas dívidas externas criaram a oportunidade para que o processo de globalização, isto é, de formação de mercados globais, fosse retomado com todo o vigor ideológico e prático, pela incorporação desses "novos" territórios.

O processo de globalização, no início do século XXI, que corresponde à expansão do capitalismo, e a sua permanente transformação tecnológica, para 
ser eficiente (maximizar o lucro), requerem a uniformização das normas que regulamentam a atividade econômica nos distintos territórios soberanos. Exige, também, retirar da arena da política a questão econômica, estabelecendo como verdade absoluta e intocável a política neoliberal em seus preceitos fundamentais de propriedade privada e de livre jogo das forças de mercado que exigem, em conseqüência, programas de privatização (que chega até à segurança e aos presídios), de desregulamentação e de abertura comercial e financeira, de redução de impostos sobre o capital e de não-discriminação entre capital nacional e capital estrangeiro.

Para auxiliar de forma poderosa essa uniformização de normas, nada mais útil do que a elaboração de teorias que advoguem o fim dos Estados Nacionais (e dos nacionalismos), o fim das fronteiras, os benefícios do Estado-mínimo, acompanhados da negociação de normas internacionais que levem à adoção pelos Estados soberanos (na impossibilidade de sua sujeição política pela força) daquelas políticas neoliberais, tornando ilegais, e até "absurdas", quaisquer políticas diferentes. Finalmente, a idéia de que a globalização econômica para ser eficiente depende de uma governança política global que assegure seu funcionamento e impeça tentativas nacionais de reversão e de limitação dos direitos de ação das megaempresas multinacionais. Todavia, paradoxalmente, o próprio processo de globalização, na medida em que não existe um Estado mundial, necessita de Estados Nacionais para internalizar as normas negociadas internacionalmente e garantir sua vigência.

Na periferia do sistema econômico e político mundial, onde se encontram os Estados que são ex-colônias, tais como o Brasil, as disparidades de renda e de poder são extraordinárias dentro de seus territórios, assim como entre essas excolônias e os países que integram o centro desenvolvido e poderoso do sistema internacional. As crescentes disparidades de poder entre o centro e a periferia do sistema, que podem ser constatadas pelo crescente hiato de renda per capita e de acúmulo de capacidade militar entre Estados desenvolvidos e Estados em desenvolvimento, fazem que os Estados, única entidade na periferia capaz de enfrentar o poder das megaempresas multinacionais, das agências "internacionais" e dos Estados desenvolvidos, sejam obrigados, para manter a convivência pacífica entre os setores da população atingidos pelas políticas neoliberais dentro de seus territórios, a procurar executar políticas de desenvolvimento e de combate à pobreza que, muitas vezes, significam restrições ao processo de formação de mercados globais e ao livre jogo das forças de mercado.

Tais políticas são chamadas de nacionalistas e "populistas", e seus defensores são acusados, criticados e ridicularizados pela imprensa a qual, hoje, na prática, é constituída por empresas multinacionais de entretenimento e informação e se encontram intimamente vinculadas às megaempresas multinacionais e delas dependentes, em conseqüência não só de seus interesses ideológicos comuns, na qualidade de empresas privadas que são, como pelo sistema de anúncios. 
Os desequilíbrios de população, território, produto, forças armadas e desenvolvimento tecnológico entre os países do centro e os países da periferia tornam na prática impossível e utópica a idéia de governo mundial, a qual é convenientemente substituída pela idéia de governança global, que na prática vem a ser exercida pelos organismos internacionais que foram criados após a Segunda Guerra Mundial para assegurar a paz, a segurança política e a estabilidade econômica ou, quando esses organismos por uma razão ou outra se verificam insuficientes ou se tornam inconvenientes, por novas agências internacionais, ou multinacionais, a serem criadas.

As tentativas permanentes dos Estados no centro do sistema de impor suas políticas econômicas e sociais, as crescentes assimetrias de riqueza e de poder entre as sociedades do centro e as da periferia, o crescente hiato entre elas, e a tentativa dos Estados do centro de impor à periferia, pela violência ou pela pressão econômica, mudanças de regime político e econômico, fazem ressurgir com mais força os movimentos antiglobalização e os nacionalismos.

Os atentados de 11 de setembro de 2001, assim como os movimentos migratórios constantes, decorrentes de diferença de oportunidades para os indivíduos entre a periferia e o centro, a que se somam ondas migratórias periódicas decorrentes de conflitos e de catástrofes naturais fizeram ressurgir nos países altamente desenvolvidos os nacionalismos xenófobos. Por sua vez, o desenvolvimento econômico na China e na Índia acrescentou uma forte demanda por energia, alimentos e minérios, o que levou à acumulação de enormes reservas pelos países exportadores de petróleo, de gás, de minérios e de commodities agrícolas. A decisão desses países de investir tais recursos (dos "fundos soberanos") em empresas dos países do centro do sistema mundial tem provocado um movimento inédito que procura impor restrições aos fluxos de capital estrangeiro que se dirigem aos países centrais, cujos dirigentes e analistas argumentam serem essas restrições necessárias por razões políticas estratégicas.

Essa rápida expansão da demanda por energia, por minérios, por alimentos de parte de países como a China e a Índia, que resultou de sua legítima aspiração de atingir níveis de consumo dignos para suas populações que correspondem, somadas, a mais de um terço da população mundial, agregada à demanda das sociedades ocidentais, tem enorme impacto sobre o meio ambiente, em especial sobre a mudança climática, cujos efeitos, para serem evitados, tornariam quase que imprescindível uma maior intervenção do Estado na economia, o que afetaria o dínamo físico e ideológico do capitalismo.

A academia, os organismos internacionais, a imprensa e os governos dos países altamente desenvolvidos permanecem, todavia, convictos de que, para os países da periferia, o nacionalismo, que é o oposto do cosmopolitismo globalizador, e o populismo, que é o oposto do liberalismo radical, são dois males gêmeos a serem atacados e erradicados a qualquer preço. Para esses países subdesenvolvidos, o melhor, para o seu bem (ou mal), seria se entregarem aos ca- 
prichos das vagas violentas da globalização radical e selvagem, cujos méritos são louvados dia e noite apesar das crises econômicas decorrentes da desregulamentação, da especulação dos mercados financeiros, do crescente hiato econômico e social entre o centro e a periferia do sistema e do renascer nos países centrais do nacionalismo econômico e do nacionalismo xenófobo contra os imigrantes da periferia. Periferia sempre vista como inferior por ser negra, índia ou amarela, bárbara, infiel e turbulenta.

Não obstante, os Estados da periferia, superadas as ilusões do fim da União Soviética, de uma Nova Ordem Mundial e dos benefícios da globalização, prosseguiram em seus esforços de desenvolvimento econômico, como no caso da China; de afirmação política, como no caso da Índia; e de luta contra a pobreza, como no caso do Brasil. Passaram a coordenar sua ação internacional, propugnando a reforma das Nações Unidas e do órgão central do sistema político-militar internacional, que é o seu Conselho de Segurança; a reforma do sistema comercial mundial por meio da atuação do G-20 na Rodada de Doha; a organização de blocos de Estados, como no caso da União Africana; a reforma do sistema de combate à mudança do clima e da matriz energética. Somente por meio de sua ação coordenada poderão defender seu direito ao desenvolvimento e à independência política em um sistema mundial que se caracteriza pela instabilidade econômica, pela violência dos poderosos, pelo desespero dos fracos, pela pobreza e riqueza extremas e pela ameaça à sobrevivência da humanidade.

RESUMO - Nação e nacionalismo correspondem a realidades que têm forte impacto sobre a política e se encontram vinculadas ao fato mais concreto da realidade quotidiana de todos os indivíduos, que é o Estado. Na periferia, o nacionalismo tem natureza radicalmente distinta dos movimentos nacionalistas que se desenvolveram na Europa, os quais tiveram sua reputação manchada pelo nazi-fascismo. O mundo real do século XXI é um mundo em que proliferam os conflitos e as divergências dentro e entre os Estados, e em que a elaboração permanente de normas e a atividade política incessante são realidades inescapáveis. As tentativas dos Estados no centro do sistema mundial de impor políticas econômicas e sociais, as crescentes assimetrias de riqueza e de poder, e a tentativa dos Estados do centro de impor à periferia, pela violência ou pela pressão econômica, mudanças de regime político e econômico fazem ressurgir com mais força os movimentos antiglobalização e os nacionalismos.

PALAVRAS-CHAVE: Nação, Nacionalismo, Estado, Globalização.

ABSTRACT - Nation and nationalism correspond to realities which have a strong effect on politics and which relate to the most concrete fact of daily life for all individuals: the State. In the periphery nationalism has a radically distinct nature if compared to the nationalist movements which developed in Europe and whose reputation was tarnished by Nazi-Fascism. The real world of the 21 st century is a world in which conflicts and diver- 
gences proliferate within and between States, and in which the permanent elaboration of norms and political action are inescapable realities. Attempts by States in the core of the world system to impose economic and social policies, the growing assimetries of wealth and power and the attempt of core States to impose on the periphery, through violence or economic pressure, changes in political and economic regimes lead to the re-emergence, on a greater scale, of anti-globalization movements and nationalisms.

KEYWORDS: Nation, Nationalism, State, Globalization.

Samuel Pinheiro Guimarães é secretário-geral das Relações Exteriores do Brasil. Foi professor da Universidade de Brasília (UnB), do Instituto Rio Branco (IRBr/MRE). É autor dos livros Quinhentos anos de periferia (UFRGS/Contraponto, 1999) e Desafios brasileiros na era dos gigantes (Contraponto, 2006). Foi eleito Intelectual do Ano 2006 (Troféu Juca Pato) pela União Brasileira de Escritores.

@ - samuel@mre.gov.br

Artigo recebido em 5.3.2008 e aceito em 7.3.2008. 